\title{
THE RECOGNITION OF EDUCATION AND QUALIFICATIONS IN THE GLOBAL COMPACT MARRAKECH
}

\author{
Marek Moška ${ }^{1}$, Peter Plavčan ${ }^{2}$
}

\begin{abstract}
This text provides an overview of the international document on the Global Compact for Safe, Orderly and Regular migration, alongside other international documents, in particular issued by the European Union, on the recognition of professional qualifications. Comments on the individual provisions of the document are also provided in connection with possible application practice.

It is based on the current state of migration in Europe and the world, and explains the causes and consequences, details of migratory waves and the consequences of non-compliance with legal regulations by individual states in this area.

In addition, the Global Compact is characterized, and the positive impacts and the requirements on important facts that are crucial for migrants in the receiving states are outlined. The negative impacts of migration in the social, economic and cultural spheres are also described.

The text lists one of the 23 objectives of the Global Compact, namely the development of skills and the mutual recognition of skills, qualifications and competences. It highlights the risks of recognizing education and qualifications from the point of view of regulated and unregulated professions in the Member States of the European Union. This issue is governed by special regulations.

Finally, the European Union Member States are recommended to focus on the actual employability of migrants on their labour markets by focusing on language courses for migrants, social assistance and, in particular, on organizing specialized courses for migrants to carry out specific activities in the field of specific occupations with employers in unregulated professions. Of course, the performance of regulated migrant professions is also proposed when meeting the requirements.

Key words: global framework, migration, recognition of professional qualifications, international document.
\end{abstract}

UDC Classification: 341.1, DOI: 10.12955/cbup.v7.1411

Keywords: global framework, migration, recognition of professional qualifications, international document.

\section{Introduction}

The new Global Compact for Safe, Orderly and Regular Migration (Global Compact, 2018) is based on the current changes in the world. For today's globalized world, mobility, or movement of people between regions, states or continents - migration - is a major feature. This is a short-term or long-term process where individuals or groups of people or entire communities leave their country of origin because of unfavourable conditions of various nature. The causes may be of an economic, political or social nature. Some of the most common reasons include: work migration, study, poor economic situation in the state, political instability, armed conflict, persecution for various reasons, corruption, family reunification or marriage. Environmental changes, such as environmental pollution, climate change or natural disasters, also cause migration.

The international community has responded to the dramatic increase in migration in recent years and has been cooperating internationally. As reported in the International Organization for Migration statistics, the total number of migrants has risen by about 100 million over the last 28 years (iom.sk, 2018).

Migration debates at a global level were held on several high-level platforms. One of the results was the adoption of the New York Declaration for Refugees and Migrants in 2016, which calls on states to protect human rights and increase aid for those who need it in this context. The Declaration on the High-Level Dialogue on International Migration and Development of 2013 also calls for respect for human rights as well as for migrant workers' rights and the protection of migrant women. These are all recommendations whose implementation is very complex in nature, organizationally and economically.

The international community, especially Member States of the European Union, has been under the pressure of migratory waves in recent years. The large numbers of people arriving in Europe report mainly armed conflicts as a reason for their migration, but also the poor economic situation in the countries of the Middle East and other African states that forced them to leave their place of residence. This massive movement to Europe in recent years is also referred to as the migration crisis. Migrants arrive in Europe using mainly two routes, namely the Mediterranean route and the Balkan route. The vast majority of migrants settled in Western and Northern European countries. This has happened

\footnotetext{
${ }^{1}$ University of Ss. Cyril and Methodius, Trnava, Slovakia, marek_moska@yahoo.com

${ }^{2}$ Danubius University, Sládkovičovo, Slovakia, peter.plavcan@vsdanubius.sk
} 
despite the fact that the European Union's migration policy obliges Member States to implement the agreed principles of migration policy in the country where the migrant entered. These principles have not been respected and large numbers of migrants have moved more or less anonymously throughout the European area, especially across the territory of the European Union. The European Union has been forced to take measures in the area of external border control and management of migration flows or integration.

\section{Strengthening cooperation for safe, orderly and regular migration}

As a result of the international community's efforts to strengthen cooperation in international migration, the Global Compact for Safe, Orderly and Regular Migration has also been created as a document that proposes recommendations for the safe and effective migration of people, especially in the Eurasian area.

The Global Compact was adopted at the meeting of heads of states and governments and high representatives in Morocco in December 2018. It is a legally non-binding document to strengthen cooperation in international migration at a global level, since no state can solve migration alone. It confirms the sovereignty of the states. It offers a comprehensive approach to facilitate safe, managed and legal migration and reduce illegal migration.

The Global Compact identifies the positive aspects of migration as a long-term phenomenon of the globalized world as it contributes to the prosperity and development of the countries. However, also important is the uniform perception of migration which is based on quality and objective information and data based on evidence of the current state of the process - the facts. For this reason, it is necessary that countries that are the target of migrants have accurate information on important facts not only about basic statistics on migrants or groups of migrants, but that information must also be available to these destination countries in the context of political, international, regional and local situations following the adoption of the EU's common documents. Failure to comply with the components of these international processes may lead to exceptional occurrences that have been witnessed in some Member States in the past. Similarly, migrants must be informed of all their rights and obligations. A very important fact is also the objectively truthful informing of the citizens of the receiving state about migration and the benefits so that it is not perceived in a negative way.

Migration also brings risks and consequences. These are primarily related to respect for human rights and the fundamental freedoms of citizens, related to the process of receiving states as well as to migrants, the provision of assistance, care, integration, and the concerns of both the country of origin and the destination country. According to Marekova (2015), nowadays, alongside all the notoriously known crises, another one has risen. The so-called migration crisis, which, by its size, can change the situation in Europe. To examine only the economic effects of this process would be therefore a very shortsighted effort. The differences in the standard of living between developing and developed countries have grown tremendously recently. Migration can manifest itself in the social sphere (changes in the composition of the society), economic area (labour market), cultural area (cultural conflicts), security (state security), politics (political decision-making and policy-making). Migration must therefore be secure, properly managed and legal in order to contribute to positive results, and all agreed commitments, as well as recommendations in international documents to be respected, and the negative consequences to be minimized.

\section{Goals of the Global Compact}

The Global Compact consists of 23 objectives, which include relevant measures considered to be policy instruments and good practices. They concern countries of origin, transit and destination.

Among the most important objectives in terms of successful and full integration of migrants into society are the development of skills and the mutual recognition of skills, qualifications and competences.

A precondition for ensuring decent work for migrants, taking into account the demographic situation and labour market requirements, but also their quality and level of education, acquired and gained knowledge and skills, is the identification of their real skills and education.

In addition to investing in skills development, it is therefore necessary to have a well-established and well-functioning mechanism to facilitate the mutual recognition of skills, qualifications and 
competencies. This is what Objective 18 of the Global Compact bounds the countries to, which would contribute to a more successful integration of migrants into society.

Deliberate creation, development, exploitation and evaluation of knowledge of the so-called "intellectual capital" of employees has crucial significance for all organizations, both to ensure their further development and to achieve and preserve a competitive advantage. In recent years, we have observed a significant increase in the importance of intellectual capital and its promotion, being the most important form of capital (Šebestová, 2010).

Member States which spend a higher above-average education expenditure percentage of the gross domestic product have, on a long-term basis, above-average and relative stability in their educational results (PISA) (Plavčan, 2018).

\section{Qualification and performance of the profession by migrants}

The digitization and technological changes that are characteristic of the present time also affect the demand for a skilled labour force with the necessary skills. These are no longer acquired through only formal education at all levels of the education system, but the importance of further education and non-formal learning gained through practice, gaining the necessary knowledge and skills, is at the forefront. Therefore, states must have rules and systems in place to recognize the results of formal and non-formal education and informal learning. This also entails the need for national qualifications frameworks and the transparency of certifications. A certain degree of harmonization between countries is possible since it is essential to respect the minimum training requirements for certain professions that each state may lay down independently or in harmonizing the minimum requirements that states may lay down together. However, global compatibility is problematic as countries have built-in national systems taking into account their specificities, capacities, priorities and needs. According to Marekova, "we face the challenge on how to confront problems of the world around us. Rising generations has to address the issues that already seemed to be resolved. How to cope with issues of cultures clash, gender differences, migration and violence. How we can co-exist if our values are completely different." (Marekova, 2018).

- Strengthening the position of migrants and societies to achieve full inclusion and social cohesion is addressed in Objective 16. Objective 16 is a commitment to actively integrate migrants into society and to minimize differences and polarization, also by increasing public confidence in migration-related policies and institutions. We quote measures to meet the commitments of the Global Compact: Promoting mutual respect for the cultures and the history of receiving communities and migrants through measures in integration policies,

- Establishing comprehensive programmes on rights and obligations, language training and social norms and customs

- Developing policy goals on inclusion in societies, including health and non-discrimination,

- Ensuring integration into the labour market to ensure work and employment with regard to qualifications,

- Strengthening gender equality in the field of employment, freedom of association and access to basic services,

- Establishing community centres for inclusion in society and engagement in mutual dialogue,

- Capitalizing on the skills and competences through mutual exchange of training, courses, vocational integration and workshops,

- Supporting multiculturalism through sports, arts and various social events,

- Promoting school environments, integrating migration information and curriculum into the content of education, and supporting schools' integration activities with targeted resources to promote inclusion and prevent hatred.

It is questionable to what extent the formulation of the Global Compact reflects the current state of recognition of education, i.e. acquired knowledge and skills to pursue a profession. The European Union itself has a number of approved documents that bind all Member States to recognise professional qualifications, such as the Directive on the Recognition of Professional Qualifications.

It directly determines the procedures for the recognition of so-called "regulated professions", that is, the professions where the law determines the conditions for its performance. Many provisions of this common law are based on agreements that have been prepared for many years and long-term 
negotiations of the Member States and it is not anticipated that the fundamental changes proposed by the Global Compact document will be applied to this legislation as rapidly as the number of migrants has risen in recent years.

With regard to unregulated professions, the performance of these professions, the way of recognition of the acquired knowledge and experience in the particular performance of the unregulated profession is in the responsibility of each Member State and employers.

Although the Global Compact document states the possibility of recognizing education in non-formal and informal learning, this option is not yet included in the legislation of the Member States in such a way as to allow for the effective recognition of the acquired knowledge and skills of migrants in the performance of specialized activities or professions. Such a model is not sufficiently developed in the legislation of the European Union nor in the Member States and not even in practice in this legal and working field between Member States. Proposals for such recognition to be made on the basis of bilateral country-by-country contracts are risky, for example the impossibility of using recognition of the migrant's qualification acquired in another Member State of the European Union than in a Member State that is a signatory of such a treaty.

In case of agreements on mutual recognition of education and professional qualifications (zákon, 2015), bilateral agreements may be concluded but regional or multilateral agreements in this area cannot be concluded as they do not take into account the specificities of all countries. These vary in education systems providing different degrees of education developed within their own countries. Qualification includes not only education, but also other components, which vary from country to country (e. g. chamber membership, integrity, etc.).

With changing labour market needs, there is also a strong need to invest in the development of new skills and competencies. In the case of migrants, it is necessary to ensure access to education, including linguistic lessons, according to established standards, as a prerequisite for employment in the labour market. In this case, cooperation and partnership between the private sector, employers and educational institutions is desirable. As we have already mentioned, this may include, in particular, international cooperation in the area of unregulated professions, in some coordination of the comparison of the required knowledge and skills needed to perform the unregulated profession according to the specific requirements of the employers in the receiving state. The standards take into account the specificities of the national education systems. Target migration states can be inspired by good practices, but a global partnership between states may be problematic due to system differences. It could therefore be more effective to engage in bilateral activities in the area of unregulated professions and specialized activities. These will mainly involve different language courses and specialized courses to perform specific activities at specific jobs in unregulated professions.

The issue of recognition of education for the purposes of performing regulated professions, particularly those of a doctor, a veterinarian, a dentist, a nurse, a midwife, an architect, a lawyer and some other, will be much more challenging. In these professions, Member States of the European Union have jointly regulated requirements on the content and duration of education.

\section{Conclusion}

The Global Compact can help with its comprehensive approach to safe, orderly and regular migration and its effective management. It is not and cannot be understood as the end of efforts in international cooperation on migration and its management. It is important to continue cooperation and dialogue at all levels - global, regional, national and local - and to ensure compliance with commitments and objectives, assess progress and exchange of experience, modifying objectives and measures as appropriate in the light of application practice and good practice. Necessary prerequisites include the consistency of government policies and the involvement of all relevant actors in the migration management process, as well as the friendly approach of states in recognizing education for the performance of a specific profession. The document thus adopted will probably also bring a lot of legislative work when preparing the new common European Union legislation, and subsequently the adaptation of the legislation of the individual Member States on the implementation of migration into special legislation.

\section{References}

Global Compact. 2018). Global Compact for Safe, Orderly and Regular migration. [Globálny rámec o bezpečnej, riadenej a legálnej migrácii.]: https://www.mzv.sk/documents/10182/3430180 
Mareková, H. (2015). Globalizácia - príčina alebo dôsledok globálnych problémov?: Vojna ako antropologicko-historický fenomén v období globalizácie sveta, [Globalization - the cause or effect of global problems?: War as an anthropologicalhistorical phenomenon during the globalization of the world.]: Vysoká škola Danubius. ISBN 978-80-8167-034-3.

Mareková, H. (2018). Udržatel'nost' hodnôt nášho kultúrneho sveta. [Sustainability of the values of our cultural world.]: Vysoká škola Danubius, 96-107. ISBN 978-80-8167-065-7.

Plavčan, P. (2018). PISA. Cesta ku kvalite. [PISA. The Way to Quality.]: MSD, Brno, ISBN 878-80-7392-302-0.

Šebestová, P. (2010). Základy celostného manažmentu sociálnej práce. [The Basics of Holistic Management of Social Work]: Vysoká škola v Sládkovičove. ISBN 978-80-89267-41-5.

Zákon č. 422 (2015). Zákon o uznávaní dokladov o vzdelaní a o uznávaní odborných kvalifikácií a o zmene a doplnení niektorých zákonov. [Act on Recognition of Diplomas and on Recognition of Professional Qualifications and on Amendments to Certain Acts.]: www.jaspi.justice.gov.sk

https://www.iom.sk/sk/migracia/migracia-vo-svete.html, 4 December 2018 . 